\title{
Use of Gramoxone 20SL (Paraquat) Prior to Land Preparation in Controlling Aquatic Weeds in Wetland Areas of Bangladesh
}

\author{
Md. Masud Rana ${ }^{{ }^{*}}$, Md. Abdullah Al Mamun ${ }^{1}$, Mohammad Habibullah ${ }^{2}$, Md. Imran Ullah Sarkar ${ }^{3}$, \\ Md. Abdul Jalil Mridha ${ }^{1}$

\begin{abstract}
${ }^{1}$ Agronomy Division, Bangladesh Rice Research Institute, Gazipur, Bangladesh; ${ }^{2}$ Product Evaluation \& Assessment, Syngenta Bangladesh Limited, Dhaka, Bangladesh; ${ }^{3}$ Soil Science Division, Bangladesh Rice Research Institute, Gazipur, Bangladesh. Email: ${ }^{\text {masudrana.brri@gmail.com }}$
\end{abstract}

Received December $13^{\text {th }}, 2013$; revised January $13^{\text {th }}, 2014$; accepted January $24^{\text {th }}, 2014$

Copyright (C) 2014 Md. Masud Rana et al. This is an open access article distributed under the Creative Commons Attribution License, which permits unrestricted use, distribution, and reproduction in any medium, provided the original work is properly cited. In accordance of the Creative Commons Attribution License all Copyrights (c) 2014 are reserved for SCIRP and the owner of the intellectual property Md. Masud Rana et al. All Copyright (C) 2014 are guarded by law and by SCIRP as a guardian.

\section{ABSTRACT}

Emergent aquatic weeds present in the monocropped fresh water wetland area of Bangladesh create a hazard in land preparation by developing dense stands. A field experiment was conducted at the farmers' field of two villages namely Mahilara and Kashemabad under Gournadi Upazila of Barisal district, Bangladesh during October 2012 to evaluate the efficacy of Gramoxone 20SL (Paraquat) in controlling emergent aquatic weeds and to find out an appropriate dose of this herbicide. Three doses of Gramoxone 20SL at $1.96 \mathrm{l} \cdot \mathrm{ha}^{-1}, 2.00 \mathrm{l} \cdot \mathrm{ha}^{-1}$ and 2.04 $l \cdot \mathrm{ha}^{-1}$ were tried with an untreated control. All treatments were laid out in a randomized complete block design and replicated thrice. There were 8 different emergent weed species infesting the field among which the most dominant weed species were Eichhornia crassipes, Pistia stratiotes, Enhydra fluctuans, Monochoria vaginalis, Echinochloa crus-galli. The results revealed that, weed control efficiency was significantly affected by different herbicidal treatments. The treatments, Gramoxone 20SL at $2.00 \mathrm{l} \cdot \mathrm{ha}^{-1}$ and $2.04 \mathrm{l} \cdot \mathrm{ha}^{-1}$ were controlled in all the emergent aquatic weeds more than $85 \%$ infesting both the sites. Application of non-selective herbicide Gramoxone 20SL at $2.00 \mathrm{l} \cdot \mathrm{ha}^{-1}$ prior to land preparation was most effective to suppress weed dry masses in both the site resulting reduced land preparation cost up to $78.93 \%$ as compared to manual weed control.

\section{KEYWORDS}

\section{Aquatic Weeds; Gramoxone 20SL; SDR; Weed Control Efficiency}

\section{Introduction}

In Bangladesh, there is enormous area of wetlands including rivers and streams, freshwater lakes and marshes, haors, baors, beels, water storage reservoirs, fish ponds and flooded cultivated fields. More than two thirds of Bangladesh may be classified as wetland according to the definition enunciated in the Ramsar Convention [1]. About 6.7 percent of Bangladesh is always under water, 21 percent is deeply flooded (more that $90 \mathrm{~cm}$ ) and 35 percent experiences shallow inundation [2]. The haors, baors, beels and jheels are of fluvial origin and are com-

\footnotetext{
"Corresponding author.
}

monly identified as freshwater wetlands. Characteristics being located in the lower edge of the topography, wetlands are subject to periodic inundation/flooding, shallow to deep, during wet monsoon. Bangladesh being situated in the sub-tropical region, the annual rainfall and humidity and the temperature is also relatively high. As such it offers a favourable environment for growth of aquatic weeds. Bodies of water in Bangladesh, therefore, are usually infested with a broad spectrum of aquatic weeds [3]. The major aquatic weeds of Bangladesh are Eichhornia crassipes, Pistia stratiotes, Nymphaea nouchalli, Monochoria hastate, Monochoria vaginalis, Sphenoclea zeylanica, Azolla pinnata, Marsilea quadrifolia [4]. 
Wetland areas of Gournadi upazila $\left(90^{\circ} 13.8^{\prime} \mathrm{E}\right.$ longitude and $22^{\circ} 58.4^{\prime} \mathrm{N}$ latitude) under Barisal district are very rich in depository of vegetations, aquatic plants, reeds and algae. A total number of 20 aquatic weeds are found in this area and its surrounding belong to 11 families having 1 shrub, 4 grasses and 15 herbs species. The wetland areas of Bangladesh covered by water almost 6 (six) months of a year starting from the monsoon. These are important monocropped area of rabi crops and boro rice cultivation of the country. The farmers of wetland area usually start their land preparation for boro rice and rabi crops in the Month of September-October after receding of flood water. In that time, the emergent aquatic weeds create a hazard in land preparation by developing dense stands on the surface of water bodies and soil. The farmers usually physically removed the emergent aquatic weeds before ploughing with country plough or power tiller. It is estimated that more than 45 man-days $\mathrm{ha}^{-1}$ is required for physical removal of aquatic weeds due to the high biomass of these weeds. Frequent physical removal of the aquatic weeds before land preparation is highly expensive, labor intensive and time consuming process. Worldwide there are 14 numbers of herbicides registered for aquatic use. These include: 2, 4-D, Acrolein, Bispyribac-sodium,Carfentrazone-ethyl, Coppers (chelate, sulfate), Diquat, Endothall, Flumioxazin, Fluridone, Glyphosate, Imazamox, Imazapyr, Penoxsulam and Triclopyr [5]. Herbicidal control of aquatic weeds seems to be a better option since it is an effective and fast acting as reported by several studies [6]. Gramoxone 20SL formulation of paraquat, manufactured by Syngenta, is used as a broad spectrum of weed control in a number of crop and non crop areas for numerous years. Paraquat is a fast-acting, non-selective contact herbicide that is absorbed by the foliage. It destroys plant tissue by disrupting photosynthesis and rupturing cell membranes, which allows water to escape leading to rapid desiccation of foliage [7]. Using paraquat for aquatic weed control enables savings in time, cost and labor by reducing or eliminating the need for manual removal of aquatic weeds in monocropped wetland areas before preparing fields for boro rice or rabi crops. Limited research information is available on use of Gramoxone 20SL for controlling emergent aquatic weeds before land preparation in wetlands of Bangladesh. Therefore, the present ex- periment was undertaken to evaluate the efficacy of Gramoxone 20SL in controlling emergent aquatic weeds and to find out an appropriate dose of this herbicide.

\section{Materials and Methods}

This study was conducted at the farmers' field of two villages namely Mahilara $\left(90^{\circ} 24^{\prime} \mathrm{E}\right.$ longitude and $22^{\circ} 92^{\prime} \mathrm{N}$ latitude) and Kashemabad $\left(90^{\circ} 23^{\prime} \mathrm{E}\right.$ longitude and $22^{\circ} 97^{\prime} \mathrm{N}$ latitude) under Gournadi Upazila of Barisal district (Figure 1) during October 2012. The area belongs to the agro-ecological zone of Low Ganges River Floodplain (AEZ 12). The climate of the area is subtropical. The experiment was carried out with four treatments; 1) $\mathrm{W}_{1}=$ Gramoxone 20SL at $\left.1.96 \mathrm{l} \cdot \mathrm{ha}^{-1}, 2\right) \mathrm{W}_{2}=$ Gramoxone 20SL at $2.00 \mathrm{l} \cdot \mathrm{ha}^{-1}$, 3) $\mathrm{W}_{3}=$ Gramoxone 20SL at $2.04 \mathrm{l}^{-\mathrm{ha}^{-1}}$ and iv) $\mathrm{W}_{4}=$ Untreated Control. The active ingredient is $20 \%$ in commercial products of Gramoxone 20SL. All treatments were laid out in a randomized complete block design with three replications. The plot size was $4 \mathrm{~m} \times 5 \mathrm{~m}$ and the total number of plot was 12 . The treatments were applied on 5 October 2012 (Site 1: Mahilara village) and 15 October 2012 (Site 2: Kashemabad village) in the undisturbed post harvest fallow land (prior to land preparation) having $5-7 \mathrm{~cm}$ standing water. The spray solution was made by mixing commercial product of Gramoxone 20SL at $4 \mathrm{ml}$ per litre water. Fresh water was used to make the spray solution. Spraying was done with the support of a knapsack sprayer in a sunny day along with good spray coverage to increase the efficacy. Data on weed density and dry weight were taken from each plot on 10 days after spraying. The weeds were identified species-wise. Weeds were sampled with the help of quadrat method and recorded. The quadrat was placed at random in the unit plot and all the weeds within each $1 \mathrm{~m}^{2}$ were uprooted, dried first in the sun and thereafter, for 72 hours in an electric oven maintaining a constant temperature of $60^{\circ} \mathrm{C}$. After drying weight of each sample were taken. The average weed dry weight was expressed in $\mathrm{g} \cdot \mathrm{m}^{-2}$. Relative weed density (RWD), relative weed biomass (RWB) and weed control efficiency (WCE) of different treatments were calculated with the following formulas:

$$
\operatorname{SDR}(\%)=\frac{\operatorname{RWD}(\%)+\operatorname{RWB}(\%)}{2}
$$

$$
\begin{gathered}
\mathrm{RWD}(\%)=\frac{\text { Density of individual weed species in the community }}{\text { Total density of all weed species in the community }} \times 100 \\
\mathrm{RWB}(\%)=\frac{\text { Dry weight of a given oven dried weed species }}{\text { Dry weight of all oven dried weed species }} \times 100
\end{gathered}
$$




$$
\mathrm{WCE}(\%)=\frac{(\mathrm{DWC}-\mathrm{DWT})}{\mathrm{DWC}} \times 100
$$

where; DWC = Dry weight of weeds in control plots, DWT $=$ Dry weight of weeds in treated plots.

Data pertaining to WCE were analyzed statistically for analysis of variance (ANOVA) following the method described by [8].

MSTAT C computer software was used to carry out statistical analysis [9]. Partial economic analysis was done based the labour wage and herbicide cost.

\section{Results and Discussion}

\subsection{Weed Infestation}

In the experimental site 1 , seven different weed species with their families were identified in control plot (Table 1). Among the seven weed species, five were broadleaved, one was grasses and the rest of one was sedges. The dominant broad-leaved weed species were Eichhornia crassipes, Pistia stratiotes, Enhydra fluctuans, Monochoria vaginalis and Ludwigia adscendens. Echinochloa crus-galli was the only grasses present in the experimental field. The experimental results showed that, Pistia stratiotes possessed the highest relative weed density (40.453\%) followed by Eichhornia crassipes (16.696\%), Monochoria vaginalis (13.313\%) and Echinochloa crusgalli $(9.493 \%)$. On the other hand, the highest relative weed biomass (RWB) possessed by Eichhornia crassipes (41.820\%) followed by Monochoria vaginalis (12.760\%) and Pistia stratiotes (12.427\%). The number of infesting weed species was slightly different in Site 2 compared to Site 1 . These weed flora were ecologically categorized into five broad leaved and a grass species (Table 1). The weed species were Eichhornia crassipes, Pistia stratiotes, Enhydra fluctuans, Monochoria vaginalis, Echinochloa crus-galli and Nymphaea nouchali. The major weed was Pistia stratiotes which relative weed density (RWD) and relative weed biomass (RWB) was at $43.700 \%$ and $14.534 \%$, respectively. The second top weed was Eichhornia crassipes which RWD and RWB value was at $20.013 \%$ and $55.760 \%$, respectively. Among the weeds Nymphaea nouchali was the minor weed with $4.170 \%$ of RWD and $3.473 \%$ of RWB, respectively. Among the weed species Eichhornia crassipes, Pistia stratiotes, Monochoria vaginalis had showed the highest RWB values in fresh water lowland ecosystem due to higher frequency of these weeds, favourable environment for persistence and easy movement of propagating materials. This is a partial conformity with the results of Sushilkumar [10] who found that $20 \%$ - $25 \%$ of the total utilizable water in India is currently infested with water hyacinth (Eichhornia crassipes).

\subsection{Weed Ranking}

The summed dominance ratio (SDR) of infesting weeds in both the experimental sites are shown in Figure 2. In the experimental Site 1, the higher rank of dominant weed was Eichhornia crassipes (SDR 33.568\%)

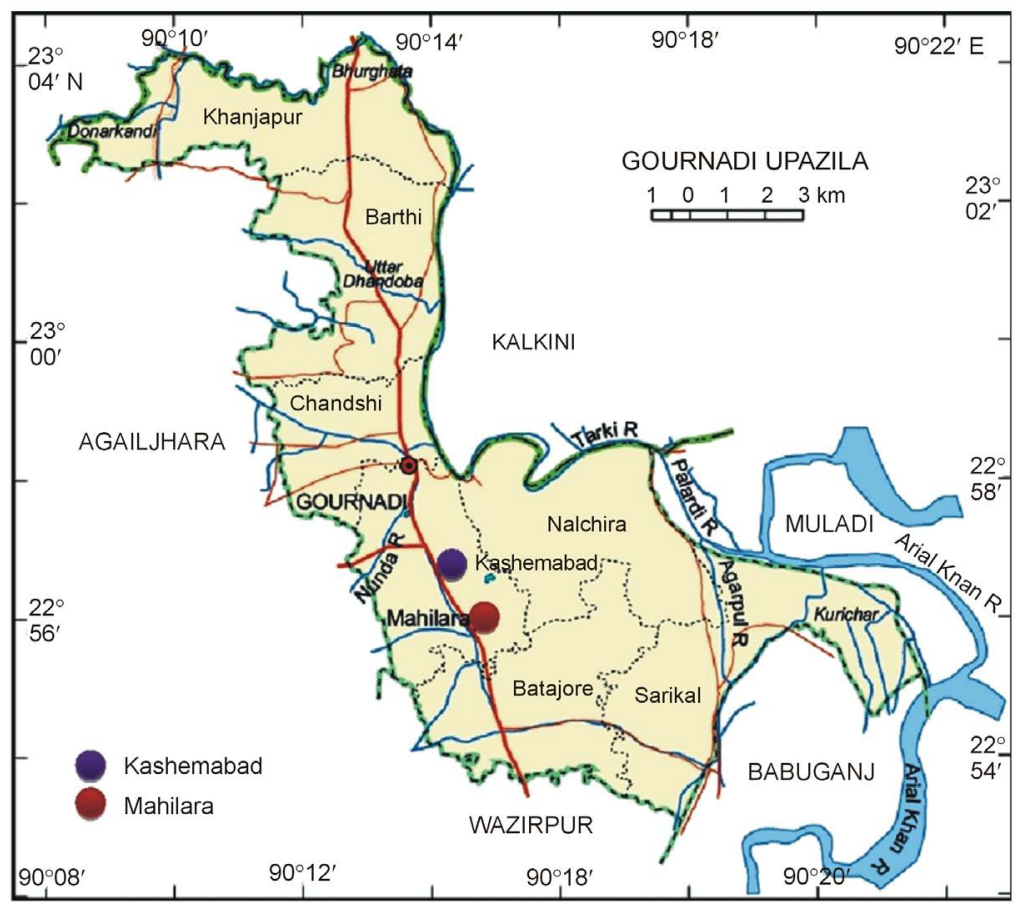

Figure 1. Study area. 


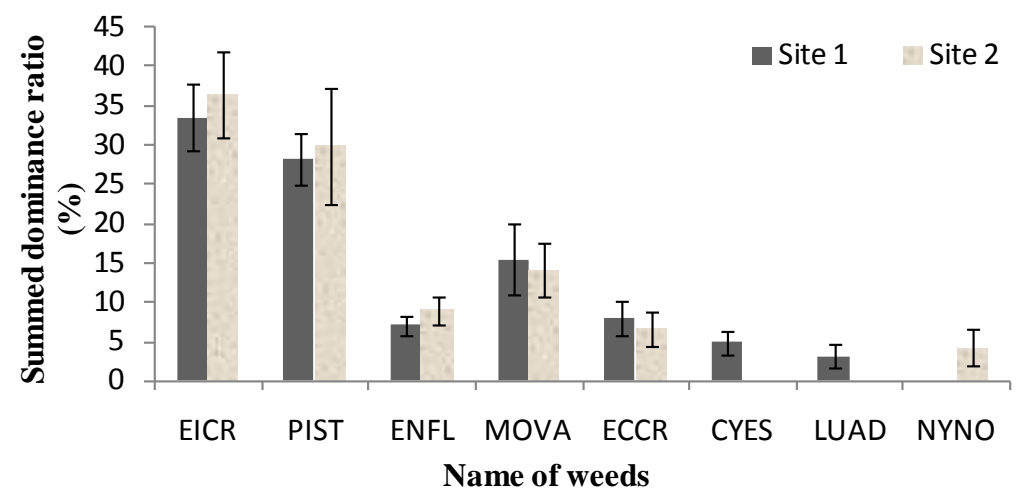

Figure 2. Summed dominance ratio (SDR) of infesting weeds. [EICR = Eichhornia crassipes, PIST = Pistia stratiotes, ENFL = Enhydra fluctuans, MOVA = Monochoria vaginalis, ECCR $=$ Echinochloa crus-galli, CYES $=$ Cyperus esculentus, LUAD $=$ Ludwigia adscendens, NYNO = Nymphaea nouchali].

Table 1. Weed composition, Relative density (\%), Relative weed biomass (RWB) and Summed dominance ratio (SDR) in the untreated control plots.

\begin{tabular}{|c|c|c|c|c|c|}
\hline Name of Weed Species & Family & Class & RWD (\%) & RWB (\%) & SDR (\%) \\
\hline \multicolumn{6}{|c|}{ Site 1} \\
\hline Eichhornia crassipes & Pontederiaceae & Broad leaf & 16.696 & 41.820 & 33.568 \\
\hline Pistia stratiotes & Araceae & Broad leaf & 40.453 & 12.427 & 28.176 \\
\hline Enhydra fluctuans & Asteraceae & Broadleaf & 9.056 & 4.088 & 7.029 \\
\hline Monochoria vaginalis & Pontederiaceae & Broad leaf & 13.313 & 12.760 & 15.394 \\
\hline Echinochloa crus-galli & Poaceae & Grass & 9.493 & 5.354 & 7.888 \\
\hline Cyperus esculentus & Cyperaceae & Sedge & 7.286 & 1.628 & 4.812 \\
\hline Ludwigia adscendens & Oragraceae & Broad leaf & 3.686 & 1.884 & 3.128 \\
\hline SE & & & 8.637 & 5.354 & 4.561 \\
\hline \multicolumn{6}{|c|}{ Site 2} \\
\hline Eichhornia crassipes & Pontederiaceae & Broad leaf & 20.013 & 55.760 & 36.453 \\
\hline Pistia stratiotes & Araceae & Broad leaf & 43.700 & 14.534 & 29.752 \\
\hline Enhydra fluctuans & Asteraceae & Broadleaf & 11.197 & 6.107 & 8.913 \\
\hline Monochoria vaginalis & Pontederiaceae & Broad leaf & 12.987 & 16.240 & 14.075 \\
\hline Echinochloa crus-galli & Poaceae & Grass & 7.920 & 5.752 & 6.616 \\
\hline Nymphaea nouchali & Nymphaceae & Broad leaf & 4.170 & 3.473 & 4.185 \\
\hline SE & & & 7.825 & 8.035 & 5.435 \\
\hline
\end{tabular}

followed by Pistia stratiotes (SDR 28.176\%) and Monochoria vaginalis (15.394\%). In site 2, similar SDR pattern was found with the value of Eichhornia crassipes (36.453\%), Pistia stratiotes (29.752\%), Monochoria vaginalis (14.075\%). The highest SDR values of these weed species are due to the high infestation, more weed biomass and favourable ecosystem for growth and development. SDR is an important indicator for showing the ranking of weeds [11].

\subsection{Weed Control Efficiency (WCE)}

Weed control efficiency was significantly affected by different herbicidal treatments. Weed density was highest in control plots $\left(\mathrm{W}_{4}\right)$. Gramoxone 20SL exhibited by lower weed biomass as well as higher weed control efficiency in both the experimental site (Table 2). In Site 1, weed control efficiency was increased with the increases of herbicide dose irrespective of weed species. Treatments $\mathrm{W}_{2}$ and $\mathrm{W}_{3}$ were controlled all the weeds more than $85 \%$. Treatment of $\mathrm{W}_{2}$ controls Eichhornia crassipes by $89.092 \%$, Pistia stratiotes $86.047 \%$, Enhydra fluctuans $98.740 \%$, Monochoria vaginalis $96.436 \%$, Echinochloa crus-galli 88.499\%, Cyperus esculentus $85.877 \%$, Ludwigia adscendens $87.903 \%$. Sharma and Singh [12] found that, application of Gramoxone Inteon showed almost completely control of grasses and broadleaf weeds even at the lower rate. 
Table 2. Effect of Gramoxone 20SL on weed control efficiency.

\begin{tabular}{ccccccccc}
\hline Treatments & $\begin{array}{c}\text { Eichhornia } \\
\text { crassipes }\end{array}$ & $\begin{array}{c}\text { Pistia } \\
\text { stratiotes }\end{array}$ & $\begin{array}{c}\text { Enhydra } \\
\text { fluctuans }\end{array}$ & $\begin{array}{c}\text { Monochoria } \\
\text { vaginalis }\end{array}$ & $\begin{array}{c}\text { Echinochloa } \\
\text { crus-galli }\end{array}$ & $\begin{array}{c}\text { Cyperus } \\
\text { esculentus }\end{array}$ & $\begin{array}{c}\text { Ludwigia } \\
\text { adscendens }\end{array}$ & $\begin{array}{c}\text { Nymphaea } \\
\text { nouchali }\end{array}$ \\
\hline & & & \multicolumn{7}{c}{ Site $\mathbf{1}$} \\
$\mathrm{W}_{1}$ & 85.373 & 81.463 & 95.639 & 93.038 & 85.773 & 81.712 & 88.000 & - \\
$\mathrm{W}_{2}$ & 89.092 & 86.047 & 98.740 & 96.436 & 88.499 & 85.877 & 87.903 & - \\
$\mathrm{W}_{3}$ & 90.887 & 84.046 & 98.785 & 96.619 & 89.679 & 84.954 & 90.889 & - \\
Control & 0.000 & 0.000 & 0.000 & 0.000 & 0.000 & 0.000 & 0.000 & - \\
LSD (0.05) & 11.276 & 5.899 & 1.649 & 8.373 & 12.075 & 4.603 & 6.686 & - \\
CV (\%) & 8.5 & 4.8 & 1.1 & 5.9 & 9.2 & 3.7 & 5.0 & - \\
& & & & Site 2 & & & & \\
$W_{1}$ & 86.076 & 82.210 & 99.967 & 87.146 & 80.950 & - & - & 96.708 \\
$W_{2}$ & 89.228 & 87.629 & 99.690 & 99.409 & 86.882 & - & - & 99.155 \\
$W_{3}$ & 88.721 & 86.689 & 99.817 & 98.659 & 84.987 & - & - & 99.692 \\
Control & 0.000 & 0.000 & 0.000 & 0.000 & 0.000 & - & - & 0.000 \\
LSD (0.05) & 17.606 & 9.437 & 0.680 & 9.747 & 11.289 & - & - & 2.482 \\
CV (\%) & 13.4 & 7.4 & 0.5 & 6.8 & 8.9 & - & - & 1.7 \\
\hline
\end{tabular}

$\mathrm{W}_{1}=$ Gramoxone 20SL at $1.96 \mathrm{l} \cdot \mathrm{ha}^{-1}, \mathrm{~W}_{2}=$ Gramoxone 20SL at $2.00 \mathrm{l} \cdot \mathrm{ha}^{-1}$ and $\mathrm{W}_{3}=$ Gramoxone $20 \mathrm{SL}$ at $2.04 \mathrm{l} \cdot \mathrm{ha}^{-1}$.

The trend of weed control efficiency in Site 2 was almost similar as Site 1. All Gramoxone treatment controlled most of the weeds more than $80 \%$. Treatment of $\mathrm{W}_{2}$ was controlled Eichhornia crassipes by $89.228 \%$, Pistia stratiotes 87.629\%, Enhydra fluctuans 99.690\%, Monochoria vaginalis 99.409\%, Echinochloa crus-galli 86.882\% and Nymphaea nouchali by $99.155 \%$, which was comparable to the treatment $\mathrm{W}_{3}$.

Linscott et al. [13] found that Paraquat (plus surfactant) applied at 1.1 and $2.2 \mathrm{~kg} \cdot \mathrm{ha}^{-1}$ to emerged weeds prior to the seeding of legumes controlled Agropyron repens and Lotus corniculatus. It was evident in the study that the non selective herbicide Gramoxone 20SL at $2.00 \mathrm{l} \cdot \mathrm{ha}^{-1}$ and $2.04 \mathrm{l} \cdot \mathrm{ha}^{-1}$ were becoming to effective for controlling aquatic weed than lower dose of that herbicide.

\subsection{Economic Analysis}

Partial economic analysis of weed control by Gramoxone 20SL vs. hand weeding for one hectare of land is presented in Table 3. By economic analysis it was observed that the maximum cost of weeding (BDT 11250.00) was involved in case of hand weeding. The treatment Gramoxone 20SL at $2.00 \mathrm{l} \cdot \mathrm{ha}^{-1}$ needed the lowest cost (BDT 2370.00) which was $78.93 \%$ lower than manual weed control cost. Maximum cost was incurred in manual weed control due to the requirement of more number of labour. This result may be supported with findings of Raju and Reddy [14] who found that, the cost of Paraquat at $1 \mathrm{l} \cdot \mathrm{ha}^{-1}$ for controlling water hyacinth was Rs. 460.00 $\mathrm{ha}^{-1}$ which was $61 \%$ lower than that of manual removal costing Rs. $1200.00 \mathrm{ha}^{-1}$.
Table 3. Economic analysis of weed control by Gramoxone 20SL vs. hand weeding for 1 hectare of land.

\begin{tabular}{cccc}
\hline \multicolumn{2}{c}{ Gramoxone 20SL } & & \multicolumn{2}{c}{ Hand weeding } \\
\hline Heads & $\begin{array}{c}\text { Cost } \\
(\mathrm{BDT})\end{array}$ & Heads & $\begin{array}{c}\text { Cost } \\
(\mathrm{BDT})\end{array}$ \\
$\begin{array}{c}\text { Labor } \\
\text { Gramoxone 20SL }\left(2.00 \mathrm{l} \cdot \mathrm{ha}^{-1}\right)\end{array}$ & 870.00 & $\begin{array}{c}11250.00 \\
(45 \text { man-days })\end{array}$ \\
$\begin{array}{c}\text { Labour for spraying } \\
(2 \text { man-days })\end{array}$ & 500.00 & & - \\
$\begin{array}{c}\text { Labour for removing } \\
\text { remaining weeds (4 man-days) } \\
\text { Total }\end{array}$ & 1000.00 & & - \\
Cost Reduction & 2370.00 & & 11250.00 \\
\hline
\end{tabular}

Labour wage at BDT 250.00 man-day $^{-1}$, Price of Gramoxone 20SL at BDT $435.00 \mathrm{l}^{-1}$.

\section{Conclusion}

From this experiment it may be concluded that, Gramoxone 20SL (Paraquat) at $2.00 \mathrm{l} \cdot \mathrm{ha}^{-1}$ applied at prior to land preparation in monocropped fresh water wetland areas of Bangladesh is effective for controlling emergent aquatic weeds. However, further research should be conducted on impact of Gramoxone 20SL on water quality, biodiversity and aquatic life in wetland areas of Bangladesh.

\section{REFERENCES}

[1] A. Nishat, "Freshwater Wetlands in Bangladesh: Status and Issues,” In: A. Nishat, et al., Eds., Freshwater Wetlands in Bangladesh: Issues and Approaches for Man- 
agement, IUCN-The World Conservation Union, Dhaka. 1993, pp. 45-53.

[2] FAO/UNDP, "Land Resources Appraisals of Bangladesh for Agricultural Development,” Agro-Ecological Regions of Bangladesh, FAO, Rome, 1988.

[3] A. A. Mamun, M. Salim, M. A. Wahab and M. A. Ali, "Aquatic Weeds of Bangladesh and Their Control," Tropical Pest Management, Vol. 33, No. 3, 1987, pp. 224228. http://dx.doi.org/10.1080/09670878709371155

[4] G. J. U. Ahmed, M. K. A. Bhuiyan, C. Riches and M. Mortimar, "Weed Identification and Management in Rice," Bangladesh Rice Research Institute, Gazipur, 2006.

[5] G. E. Macdonald, “The Development and Implications of Herbicide Resistance in Aquatic Plant Management,” $\mathrm{Pa}$ kistan Journal of Weed Science Research, Vol. 18, Special Issue, 2012, pp. 385-395.

[6] U. N. Uka and K. S. Chukwuka, "Chemical Control Method as a Management Approach to Water Hyacinth Infestation in Nigeria,” Zonas Aridas, Vol. 12, No. 1, 2008, pp. 184-190.

[7] R. J. Dinis-Oliveira, F. Remiao, H. Carmo, J. A. Duarte, A. S. Navarro, M. L. Bastos and F. Carvalho, "Paraquat Exposure as an Etiological Factor of Parkinson's Disease," Neurotoxicology, Vol. 27, No. 6, 2006, pp. 11-22. http://dx.doi.org/10.1016/j.neuro.2006.05.012
[8] K. A. Gomez and A. A. Gomez, "Statistical Procedure for Agricultural Research,” 2nd Edition, John Wiley and Sons, New York, 1994.

[9] B. Bricker, "MSTATC: A Micro-Computer Program for the Design, Management and Analysis of Agronomic Research Experimentation,” Crop and Soil Science Department, Michigan State University, East Lansing, 1991.

[10] Sushilkumar, “Aquatic Weeds Problems and Management in India,” Indian Journal of Weed Science, Vol. 43, No. 3-4, 2011, pp. 118-138.

[11] R. Shultana, M. A. A. mamun, S. A. Rezvi and M. S. Zahan, "Performance of Some pre Emergence Herbicides against Weeds in Winter Rice,” Pakistan Journal of Weed Science Research, Vol. 17, No. 4, 2011, pp. 365-372.

[12] S. D. Sharma and M. Singh, "Gramoxone Inteon-A New Formulation for Weed Management in Citrus," Proceedings of the Florida State Horticultural Society, Vol. 119, 2006, pp. 172-176.

[13] D. L. Linscott, A. A. Akhavein and R. D. Hagin, "Paraquat for Weed Control Prior to Establishing Legumes," Weed Science, Vol. 17, No. 4, 1969, pp. 428-431.

[14] R. A. Raju and M. N. Reddy, "Control of Water Hyacinth through Herbicides,” Indian Farming, Vol. 38, No. 3, 1988, pp. 19-21.

\section{List of Abbreviations}

\begin{tabular}{ll}
\hline AEZ & Agro-ecological zone \\
ANOVA & Analysis of variance \\
BDT & Bangladeshi Taka (Currency of Bangladesh) \\
cm & Centimeter \\
CV & Coefficient of variation \\
et al. & And others \\
FAO & Food and Agriculture Organization \\
g & Gram \\
ha $^{-1}$ & Per hectare \\
l & Litre \\
LSD & Least significant difference \\
$\mathrm{m}^{2}$ & Square metre \\
Rs & Indian Rupee \\
RWB & Relative weed biomass \\
RWD & Relative weed density \\
SDR & Summed dominance ratio \\
SL & Soluble liquid \\
SE & Standard error \\
t & Ton \\
WCE & Weed control efficiency \\
$\%$ & Percent \\
\hline
\end{tabular}

